\title{
Good Governance and Leadership: Pathway to Sustainable National Development in Nigeria
}

\author{
Nicholas Omoregbe Olanike Sharon (Corresponding Author) \\ College of Business and Social Sciences, Covenant University \\ Email: sharon.nomoregbe@ covenantuniversity.edu.ng
}

Tel: +2348032411218

Kehinde Oladele Joseph

Dept. of Business Management

College of Business and Social Sciences, Covenant University

\author{
Imhonopi David \\ Department of Sociology \\ College of Business and Social Sciences, Covenant University \\ Evbuoma Idowu Kikelomo
Department of Psychology \\ College of Leadership Development Studies, Covenant University
}

Received: January 23, 2016 Accepted: February 11, 2016 Published: February 21, 2016

doi:10.5296/jpag.v6i1.9055 URL: http://dx.doi.org/10.5296/jpag.v6i1.9055

\begin{abstract}
The concept of governance and leadership are intertwined. Good governance and leadership is critical for the achievement of results. It is often said that no country can develop beyond the level of its leadership. The predicament of Nigeria in terms of underdevelopment and corruption can be adduced to the problem of leadership and governance. Nigeria needs committed leaders who will govern with integrity and doggedly influence its human and natural resources toward the actualization of sustainable national development. This paper is descriptive; it looks at the place of leadership and good governance in the actualization of
\end{abstract}


overall national development in Nigeria. Transformational leadership theory and contingency theory of leadership viewpoints are examined vis a vis diverse impediments to national development in Nigeria, as vital to feasible and substantial national development; The paper recommends that; The leaders who govern should be made accountable by publicly declaring what they have been able to achieve in terms of performance as well as how much was expended in every sector on a yearly basis; Auditors with integrity should be made to verify their claims in order to ascertain the genuineness of the claims; Corrupt leaders should be brought to book and made to face necessary and lawful penalties without fear or favour; and elections made free and fair and not rigged. When citizens are allowed to choose their leaders, leaders would in turn have a sense of responsibility that they owe the people good governance.

Keywords: Accountability, Corruption, Citizens, Transformational, Society

\section{Introduction}

Nigeria was colonized by the British in the $18^{\text {th }}$ century, but later got its independence in 1960. Prior to that time, Nigeria was noted for its richness in agricultural produce through which she earned its foreign exchange, and built its reserve. In the $19^{\text {th }}$ century, Nigeria was the world's largest exporter of cash crops such as cocoa, groundnuts, palm-oil and food crops like cassava, yams, and sugarcane (Claude 1996). In the late 60s, petroleum was discovered in Nigeria, coinciding with the military coups and rule. At this time, the military regime hindered economic development in Nigeria by ushering in bribery and corruption, mismanagement, looting of treasury, killing, maiming, and nullification of elections (Shobola \& Nicholas-Omoregbe 2012).

The discourse on the delicate future of Nigeria is strictly connected to the failure of governance and leadership. The human and infrastructural development curve of Nigeria is on the downward drift, in spite of the increase in oil revenue over the past three decades. Obviously, the actions of economic and political managers who are highly dependent on oil lease have exposed the Nigerian State to oil resource spell (Iyoha, Gberevbie, Iruonagbe \& Egharevba 2015; Nyeswusira \& Nweke 2014).There is an agreement among policy makers, development scholars, and institutions that the wealth of a nation has strong relationships with its type of governance, leadership and social policy framework (Kaufmann 2013; Bardhan 2005). Leadership is important to demonstrating better-quality governance, which enhances societal development, because it is a process of influencing the actions of a structured group towards the setting and attainment of goals.

\section{Objectives}

The objectives of this paper amongst others are: (i) to ascertain the place of good governance and leadership as necessary catalyst to satisfactory development of any society; (ii) to establish leadership commitment and good governance as fundamental to the survival and progress of any nation; (iii) to offer solution to poor governance as well as ineffectual anti-corruption policies in Africa; (iv) to offer useful recommendations which policy makers 
at the various tiers of government will find beneficial when faithfully implemented.

\section{Methods}

This study utilizes qualitative research techniques in trying to critically evaluate the concept of good governance and leadership as the pathway to sustainable national development in Nigeria. It therefore uses secondary sources of data such as Text Books, Journals, Magazines, Newspapers and the Internet. Conclusions and useful policy recommendations were made based on the above descriptive designs.

\section{Literature Review}

\subsection{Conceptual Framework}

\section{a. The Concept of Governance}

Governance, a concept that is greatly debated, is now inviting greater attention within and amongst countries and as the number of democratic administrations is continuously increasing, good governance has evidently become a key standard to judge a nation's credibility as well as respect on international scales (Iyoha, et al 2015). Governance refers to several ways by which social life is coordinated. It is a process of social engagement between the rulers and the ruled in the society which implies that governance is predicated on the relationship between the ruling class and the ruled class in the society (Iyoha, et al 2015; Nyewusira 2007). Governance can be referred to as the traditions as well as institutions that define how authority is exercised in a given country (Kaufmann, Kraay \& Zoido 2000). Salman (2009) asserts that Governance entails the procedure through which governments are selected, monitored, held accountable, and replaced; it is government's ability to judiciously manage resources well and formulate, implement as well as enforce good policies and regulations; and the respect of citizens and the state for the institutions that govern economic and social interaction between them (Salman 2009).

According to Kolade (2012), Governance involves participation by both the governor and the governed (i.e. the leader and the follower). He asserted that in order to get the expected governance in Nigeria, there is the need to provide 'leadership education that highlights service delivery, quality and accountability; severely curtail the excesses of position holders, encourage the culture whereby position holders vacate office when being investigated for wrong doing; and openly celebrate leaders that excel or perform well. Recently, good governance has been an important subject in economic development discourse because of its connection to information dissemination which, could improve resource allocation, enhance efficiency and increase the prospects of economic growth provided it is made available on time and without being distorted. Ijaya \& Ijaya (2004) asserted that this is a vital pre-requisite for the improvement of wellbeing of the citizens. A general agreement has been building throughout Africa that good governance is indispensable for transforming its economy. Certain qualities are connected with good governance, which comprises protecting respect for human rights, justice and rule of law; strengthening democracy through public participation and pluralism; encouraging transparency, accountability, anti-corruption policies and practices and capacity in public administration (UNDP 1998; World Bank 1989).Good 
governance is indispensible for institutional growth and effectiveness. According to Akanbi (2004), good governance is the capability of a government to sustain social peace, guarantee law and order, promote conditions needed for generating economic growth and ascertain a minimum level of social security. Development will be a mirage where good governance is lacking. Good governance is hinged on the capacity to exercise power and to make sound decisions over a period of time in economic, social and environmental areas (World Bank 2005).

Dickson (2011) asserts that if the sectors (power, education, health, manufacturing, etc) in Nigeria are expected to work, then, Nigeria needs good governance so as to be able to actualise its potentials and improve the wellbeing of the citizens and development in geo-political terms. He said that the word 'good' is one fundamental thing that is absent in the governance of Nigeria. Good governance has been perceived as the most significant factor in eradicating poverty, inequality, as well as promoting development (Khan 2007). Many Nigerians are of the opinion that good governance is the only assurance to peace, progress, stability, free and fair elections; actually, it is seen as the only means to delivering the dividend of democracy.

Dickson (2011) said that good governance in relation to a popular democracy ought to be hinged on two basic things; the first is a constitution fit to the distinct needs and circumstances of Nigeria as ethno-religious, multi-dimensional, and political economic structure. Secondly, a leadership fit not only to the pressing needs of Nigeria but the exact needs of its citizens. He reiterated that generally, good governance does not call for ordinary type of leadership but it requires tolerance, breadth of outlook, intellectual comprehension, hard work, selfless devotion, statesmanship, a burning sense of mission, etc. to make a success of leading Nigeria as a nation. Gyimah-Boadi (2005) opines that democracy is not ever a finished project but it is constantly a work-in-progress that could progress, stagnate or retrogresssubjectto the actions as well as lapses of the government and the governed.

\section{b. The Concept of leadership}

The leadership question is hinged on the interface of structure and behaviours, dialectic of persons and institutions. It connotes actors who create, implement or interpret the laws that are binding on existing social institutions and play the state roles (Dagaci 2009). Leadership is one of the concepts that is difficult to be given a universal definition because it is applicable to every facet of life. Leadership and leading activity is obtainable in the home, at work, religious settings and invariably where there are groups of people, there expects a leadership aura. However, the orthodox meaning of leadership is for an individual within a group to lead and others follow. But over the time, people's perception of leadership begins to change because of the different roles the leaders have to perform in different places. Consequent upon this, it is often said that some leaders are born while others inherit leadership traits (Shobola \& Nicholas-Omoregbe 2012). Leadership is very critical to providing better governance; it advances societal development, as it is a process of influencing the activities of an organized or structured group towards the setting and attainment of goals. Consequently, underscoring the issue of effective leadership in modern 
societies is the manner in which politics is played as well as what the people who seek power use it for that eventually shapes the outcomes of governance and development in that nation (Iyoha, et al 2015; UNDP 1998; World Bank 1989).

Adepoju (1998) examined leadership in twofold ways, viz: (a) as an organizational position as well as (b) as an influence process. He further explained that leadership as an organizational position talks abouta person who has been put in a leadership or decision making- role. The second view stresses that a leader inspires others to follow. This gives an idea of the dynamics of leadership as a way of influencing others towards the realization of organizational goals. Ajadi \& Adedeji (2009) explained that a leader is seen as the force that initiates action amongst people and guides the activities in a particular direction; maintains the activities and unites efforts towards collective goals.

In any case, a leader is one who exercises uncommon influence as well as considerable power. Gardner (1978) describes a leader as someone who understands the challenges that all in the society must face, to assist in the setting of goals and priorities, to work with others in finding paths to those goals chosen, maintaining public morale, and motivation and nurturing a workable level of public unity. This, implies that a leader must possess the power or influence of transforming something common into something valuable. The qualities of good leadership according to Orji and Ekpo (2010) include transparency, accountability, honesty, diplomacy, etc. A leader is someone who leads a group of people in the direction ofthe accomplishment of set goals.

All human organizations and societies have someone or few persons who are charged with the responsibility of encouraging the course of the group action towards realizing its goals. Uchendu (1995) views leadership as the ability to manage, coordinate and motivate others towards the realization of organizational goals. It is critical for the achievement of results. Morphet, John \& Reller(1982) describes leadership as influencing the actions, behaviour, beliefs and goals of an actor in a social system by another with the willing support of the actor being influenced. This explanation lays emphasis on social order between the leader and the follower. Amali (1979) opines that a leader is someone who shows the way, and guides another person or group of persons to attain a goal. The leadership process is hinged on the capacity to allocate scarce resources, which determines the locus of power (Dagaci 2009). Effective leadership is central to the attainment of success. Leadership is a privilege to serve and should be viewed as such and not a display of power or opportunity to accumulate wealth (Kolade 2012). The past leadership problems in Nigeria could be linked to questionable personalities of the rulers. Elections were rigged in order to impose self on the people. The political leaders more often than not gain control of state structures so as to access economic rewards. Mamora (2012) pointed out that leadership starts with self, according to him, "if you cannot lead yourself, how can you lead others?" Countries that have leaders that are accountable are more liable to win the fight against great poverty and disease. Transparent governments that respect civic participation and the rule of law are required to make certain that scarce resources are well spent and investments are made in the poor people. 


\section{Macrothink}

Journal of Public Administration and Governance

ISSN 2161-7104

2016, Vol. 6, No. 1

Kolade (2012) asserted that Nigeria will continue to grope in darkness of maladministration unless it adopts a system that enables people to grow into leadership positions via experience and performance. He added that it is only good leadership that can bring Nigeria out of the brink of collapse and that the essence of leadership is about producing an environment where individuals regularly perform to the best of their capability. He pointed out that most people in positions of authority in Nigeria see themselves as rulers rather than leaders and by so doing "they dispense instructions from a superior position of authoritarian power and they think that they are above the law, whereas a leader sees himself as "a first among the people" and subjects himself to the same rules that binds every other person.

\subsection{Theoretical Framework}

\section{a. Transformational leadership Theory}

This leadership theory believes that the challenges facing the world in contemporary times require a new kind of leadership. Those who believe in this theory view it as consisting of two complementary roles, that is, the mover-and-shaker and the gentle persuader. The mover-and-shaker is seen as someone who achieves transformation in an organisation's fortunes. While a gentle persuader transforming leader can be viewed as someone who transforms followers into leaders by persuading them to see beyond their own self-centeredness for the good of the whole, he encourages followers to consider long-term rather than immediate needs, and to become more aware of and accepting an organisation's goals.

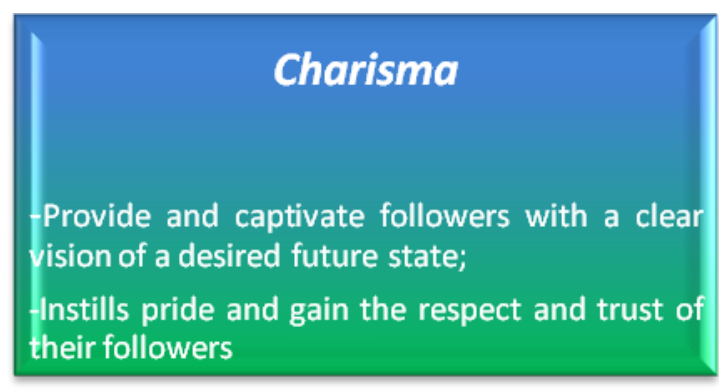

\section{inspirational motivation}

-Inspire followers in an exciting manner with the idea that they can achieve great things just with the input of extra effort

individualized consideration
-Pays close attention to differences among
followers;
-Serve as mentors to those who need to be
futored and advised;
-Treats each follower as an individual worthy
of respect

\section{intellectual stimulation}

-Requires by encouraging innovative ways of looking at old problems; not maintaining the status quo;

-Sees difficulties as mere challenges to be met and overcome;

-Lays emphasis on creative thinking.

Figure 1: Transformational Leadership Framework

Source: Authors' compilation (2015) 


\section{Al Macrothink}

Journal of Public Administration and Governance

ISSN 2161-7104

2016, Vol. 6, No. 1

Characteristically, transformational leaders accomplish unusual performance via the four leadership factors of charisma, inspirational motivation, individualized consideration and intellectual stimulation. Consequently, transformational leaders use charisma to provide and captivate followers with a clear vision of an anticipated future state, they instill pride and gain the respect and trust of their followers. They inspire the followers in an exciting manner with the idea that they could accomplish great things just with the input of more effort. Additionally, transformational leaders exhibit individualized consideration by paying close attention to differences among followers, serving as mentors to those who need to be tutored and advised, and treating each follower as an individual worthy of respect. Lastly, transformational leaders provide followers with intellectual stimulation they require by encouraging innovative ways of looking at old problems; not maintaining the status quo, seeing difficulties as mere challenges to be met and overcome and laying emphasis on creative thinking.

Those who support transformational leadership believe that it could define an organisation's success and failure. These advocates established that followers under the leadership of transformational leaders are not only more satisfied, but they also do better jobs (Yalokwu 2006).

\section{b. Contingency Theory of Leadership}

Contingency theories of leadership center on specific variables or factors related to the environment that could determine which exact style of leadership is best suitable for the situation (in the Nigerian context, particular variables such as corruption, poverty, etc. call for types of leadership that both transformational and sensitive and accommodating to the multicultural context of ethnicity, focused towards development). This theory asserts that no leadership style is best in all situations. Success hinged on a lot of variables, including the leadership style, qualities of followers and facets of the situation. This appears relevant for the Nigerian context, in which, in the present situation an 'eclectic' approach (what works) is key to transformation.

\section{Impediments to National Development Consequent on Poor Governance and Leadership}

Olomola (1996) describes development as the advancement made through progressive and qualitative alterations in social, economic, cultural, technological as well as political conditions of a society, leading to an enhancement in the welfare of citizens. There are diverse impediments to national development with particular reference to Nigeria.

Lack of good governance is a major impediment to national development. The quality of governance is the major determinant of a country's economic development. Good governance is partly characterized by creation of employment, security of life and properties. Security of lives and properties is fundamental to good governance. Good governance is thus an ingredient that provides a conducive environment for foreign investors which can promote economic growth and development (Bello \& Lamidi 2009). The most topical issue in the governance of contemporary Nigerian nation is probably accountability and 
transparency in the handling of public funds. Accountability is a central part of governance which is characterized by foreseeable, open and enlightened policy making (i.e. transparent process). Transparency is another vital aspect of good governance. Transparency and accountability go hand in hand. Transparent decision making is crucial for public sector in making sound decisions for better performance (Afolabi 2004). Kolade (2012) asserted that the abuse of authority, and privilege of office; the absence of culture of accountability; and the inadequacies of stakeholder's dynamism could all hinder true/good governance.

Another huge hindrance to national development is corruption such as greed among the political leaders largely characterized by embezzlement and misappropriation of public funds, cheating, bribery, forgery, impersonation, rigging, hoarding of voters cards, multiple voters' registration, etc. which has constituted a huge impediment to development in Nigeria (Dagaci 2009). Corruption is one of the greatest threats to good governance today (Iyoha, et al 2015). It is a social problem which hampers development and robs people of the chances for any significant economic as well as social advancement (Okeyim, Ejue, \&Ekanem 2013).Corruption slows down economic growth and investment. Economic growth and development in Nigeria for over twenty years has been soiled with misappropriation and embezzlement of funds even with the return of democracy, turning the country's economy into an underdeveloped nation with least position in international ratings (Abullahi 2009). The Corruption Perception Index (2013) published by Transparency International shows that Nigeria occupies the $144^{\text {th }}$ position in the world. This plunged downward further from the $137^{\text {th }}$ out of 177 countries surveyed in 2012. However, Nigeria was ranked as the $136^{\text {th }}$ most corrupt country in the world in 2014 bettering the position of 2013 by eight places.

Public policy in Nigeria is focused on the 'affluent few' and only pays lip service to the 'afflicted majority'. The quick transfer of public wealth to the ruling elites and their allies under the pretense of privatization, the allocation of $25 \%$ of the recurrent expenditure of the Federal Government to just 469 members of the National Assembly attest to this fact (Ibeanu 2008).Corruption is wasteful because of the manpower used in monitoring and investigating corruption (Dike 2010).Corruption lessens the ability of the state to carry out its statutory obligations of providing social services such as healthcare, education, good transportation system, water, etc. Once these services are not provided, the consequence would be underdevelopment. Also, corruption has the capability to hamper investments, slow down social, economic, and political development, as well as endanger democratic values and increases distrust among citizen as well as investors. The likelihoods of instability in society are also increased since corrupt political leaders are usually under incessant fear of being overthrown or removed (Okeyim, et al 2013).Corruption is a scourge that is rapidly eating up our national entrails, subverted our national dreams and stunted our growth (Dagaci 2009). Misappropriation and embezzlement is a type of behavior demonstrated by a public servant whether elected or appointed which includes a deviation from his or her formal duties because of personal gains to himself or herself or to other private persons with whom the public servant is connected (Abdullahi 2009). The effect of corrupt practices by the leaders is the erosion of accountability and transparency and a reduction in the quality of governance (Oshodi 2009, citing Ogwu 2002). The most topical issue in the governance of contemporary 
Nigerian nation is probably that of transparency and accountability (Afolabi 2004). Governance in Nigeria as correctly observed is about creating affluence for a few and not about eradicating affliction for the many (Ibeanu 2008). That is why it has been argued that the bane of Nigeria's development is that crucial institutions of government are administered by a ruling class that lacks governance capability and contract management culture (Nyewusira 2007). Corruption hurts the poor extremely and increases income inequality because it allows certain persons or groups of individuals to take advantage of state activities at the cost of the rest of the population. For example, after corruption has led to shoddy public services, the poor have no other choices because they cannot turn to the private sector, like private schools, hospitals, security or garbage collection which is more far expensive (Okeyim,et al 2013).

Poverty is another impediment to national development. Nigeria is still ranked amongst the poorest nations in the world (Agu 2013). Jhingan (2001) views poverty as hunger, lack of shelter, not being able to speak out, lack of job, fear of the future, lossof a child to illness (probably caused by unclean water or inability to pay medical bills), lack of representation and freedom, powerlessness, and probably inability to generally pay hospital bills. In spite of the presence of abundant human as well as material resources, many Nigerians are still poor. It is apparent that the wealth of any nation is dependent on efficient government, reasons being that it is the government that helps to maintain the social contract that binds members of the country or state together (Ejuvbekpokpo 2012). Poverty is an outcome of corrupt practices by the leaders; this is corroborated by Bello \& Lamidi (2009) who said that corruption is a social problem that creates a foundation for the existence of poverty because the resources meant for development in the country are being diverted to private uses. The African Peer Review Mechanism Team during their visit corroborated the fact that political or economic corruption increases poverty in Nigeria (Akpe 2008). The income of many citizens is so meager such that it could hardly cater for their basic or philosophical needs as propounded by Abraham Maslow in his Needs hierarchy. Inflation which is prevalent in Nigeria brings about poverty. The aftermath of poverty is social vices such as stealing, armed robbery, abduction, etc. Poverty has torn the moral fabric of the society and it now threatens the existence of the country with violent eruptions and conflicts among different groups.

Violence and crime is an impediment to national development. Violent crimes like armed robbery, murder, kidnapping, abduction, terrorism are the greatest inhumane crimes that plague Nigeria (Iyoha, et al 2015). Recently, kidnappings for money as well as terrorism have taken over culminating in bloodshed and economic set-backs (Ajaegbu 2012). Socio-economic inequalities as well as the lack of opportunities for social advancement and employment arecertain causes of crime and violence (UN-Habitat, 2008). Violence can also be explained by joblessness and intense competition over scarce resources and services in the society (Bello \& Lamidi 2009). The Boko Haram insurgency poses a great threat to national development. Boko Haram insurgency has led to heavy loss of human lives and property and it has also displaced 33, 169 persons between 2013 and 2014 (Soyinka 2014). Furthermore, paradoxically, Nigeria as a country which reports strong economic indices such as strong real 
GDP growth of average 6.5 percent in the past decade still has unemployment rate that is rising annually from 11.9 percent in 2005 to 19.7 percent in 2009, and over 37 percent in 2013 (Aganga2010; Ogunmade 2013; Asaju, Arome \& Anyio 2014).

Lack of sustainability of projects and programmes is another huge impediment to national development. Many laudable and capital-intensive projects/programmes enacted or started by preceding leaders have been disregarded or neglected by their successors in a bid to be able to assign or approve new or fresh ones due to selfish intentions for financial gains. Many times, good and potentially impactful and viable projects or programmes have been abruptly stopped or neglected by succeeding leaders. Many government projects that have the capacity to reduce poverty in Nigeria were not executed by the corrupt officers and none of these contractors/officers have been prosecuted for non-execution of the contracts, rather, it is the poor that has been deprived of the benefits of such projects that bears the burden of the corrupt officials(Oshiomole 2003; Bello \& Lamidi 2009). African countries have never lacked commendable ideas on how to deepen democracy, promote transparent governance, and sustainable development; but the challenge has always been the political commitment to transform the excellent good governance ideas and policies into practicable and sustainable development projects except for implementation issues (Ikubaje 2014).

Tribalism is also a great hindrance to national development. Nigeria is made up of many diverse ethnic groups (about 250 ethnic groups) with various languages and customs making it a country of rich ethnic diversity and tribes. This diversity usually leads to nepotism. Leaders tend to favour the group or tribe they belong to which does not augur well for national development.

Another great impediment to national development is debt. The heavy debt which was acquired over the years was graciously cleared during the political reign of General Olusegun Obasanjo but has been acquired again during the reign of Late President Yar'adua and President Goodluck Ebele Jonathan. The acquired debt would not and does not augur well for economic and social and social development.

\section{Curbing Corruption and Panacea to Good Governance in Nigeria}

The underdevelopment witnessed in Nigeria can be attributed to the issue poor governance and corruption. Aluko (2006) has recommended ways through which corruption could be curbed in Nigeria which will bring about good governance and accountability on the part of government. Some of the recommendations will be looked at.

- Involvement of the Masses in the Activities of Government

In order to promote public awareness of the tasks, policies and priorities of government, transparency is needed at all levels of government. The programmes of government at all levels as well as their expected outcomes should be made clear. Furthermore, any occurrence of corruption at any level of government, as well as the cost to the system, should be exposed. These public enlightenment measures are required as part of an empowerment plan to ensure popular participation. In order to get rid of the pervasive apathy within civil society, Government has to be accountable to the people. 
The mechanisms provided for civil society to hold effective consultations with and monitor their elected representatives at all levels need to be publicized and strengthened. Accountability brings about transparency in governance such as transparency in decision making, and policy formulation. The masses and their representatives should hold regular meetings with government representatives where mind bugging questions and issues can be discussed in relation to the development of their communities and the welfare of the people through community or town hall meetings. The representatives are then expected to go and hint the people in government about the demands of the people, what they are aggrieved about and what they are pleased with regarding the governance of the incumbent leader.

Additionally, there is also the need to ensure the existence of a regularly reviewed and periodically updated code of ethics to guide the performance of legislative functions at all times. This requires adequate publicity to enable civil society to monitor its enforcement. If government wants the masses to be actively and excitedly involved in the execution of government's priorities, then they should involve the people in the process of setting them up. The principle of participatory budgeting should also be adopted.

- Non-Governmental Organisations and the Media Need Capacity Building and Empowerment

There is an urgent need for the media, as the fourth estate of the realm, to strengthen its investigative and monitoring capacity and foster greater professionalism and integrity, in the conduct of its affairs. The press should be allowed to discharge its duties freely without fear or favour. The media and nongovernmental organizations (NGOs) should act as the ultimate watchdog institutions by closely monitoring the political process, party financing, the effectiveness of representation, performance of government service delivery agencies and regulatory institutions. The private sector on its own part should support and fund the NGOs. These institutions also need to develop survey techniques as well as advocacy and lobbying skills. They should conduct annual surveys on the nature, incidence and extent of corruption in Nigeria. This effort will go a long way to complement the efforts of government.

\section{- Reintroduction Of Ethics And Civics Into The Curriculum}

The need for a reintroduction of ethics and civics into our educational curriculum right from primary school all through to secondary school is fundamental in the curbing of corruption in Nigeria. "Catch them young" should be the focus in curbing corrupt practices. When the right values, norms, ethics, culture, character, etc. is inculcated early in Nigerian children and youths and well imbibed by them, it would shape their personality and would set a standard for their behaviour later in life. Successively, ethics and civics can also be integrated into the curriculum of higher institutions in form of "General Studies" courses for consolidation of what was learnt at the primary and secondary school levels.

- Pillars Of Integrity

It is integrity that can make a man or woman incorruptible and the lack of it makes a man or 
woman corrupt. The religious bodies in particular, the traditional rulers, as well as media should come more alive to their civic responsibilities by consistently/regularly teaching and preaching to Nigerians on the virtue of integrity and the dangers of the lack of it on the community, self and Nigeria as a whole. In other words, the vision and strategy for an effective anti-corruption drive should, in the long run, evolve around particular 'pillars' of integrity such as professional associations, the media, religious bodies, and the systems of traditional rule. They all need to be strengthened.

\section{Conclusion}

Good governance and leadership is fundamental if development and progress is to be attained in any country. Leadership commitment and good governance is fundamental to the survival and progress of any nation including Nigeria. And it is the responsibility of all to ensure and demand for good leadership and effective governance. Nigeria needs a leader who is incorruptible with integrity, focus, commitment, determination, selflessness, discipline, and enterprising personality in order to attain all round development. Ikubaje (2014) is of the opinion that the way out of poor governance and ineffective anti-corruption policies in Africa is a collective will of both the political leadership as well as the citizens.

\section{Recommendations}

Accountability should be given its proper place in Nigeria. The leaders should be made accountable by publicly declaring what they have been able to achieve in terms of performance as well as how much was expended in every sector on a yearly basis and auditors with integrity should be made to verify the claims in order to ascertain the genuineness of the claims. This will in no small measure lessen the level of corruption, misappropriation and embezzlement of funds and enhance the leadership roles of our Nigerian leaders thereby bringing in probity.

The judicial arm of government should be made or empowered to function effectively so as to ensure that corrupt leaders are brought to book and made to face necessary sanctions and penalties which would serve as deterrents to others. Elections should be made to be free and fair and not rigged. When citizens are allowed to choose their leaders, the leaders would in turn have a sense of responsibility that they owe the people for good governance.

Furthermore, Nigerians should stop celebrating corrupt officers, celebration of corrupt officers is legalizing corruption as if 'it does not matter', as if corruption is 'right or acceptable'. Corrupt officers should not be accepted into the society when they have left offices or jail in anyway, this will make their stay in the society uncomfortable and it will serve as deterrent to others who will find themselves in governance subsequently.

Finally, the masses should hold the government responsible (accountable) for their stewardship to them; Nigerians should no longer be silent on poor government policies. People need to hold their destinies in their hands and make government to be alive to its constitutional responsibility of maintaining law and order, security, and provision of enabling 
environment as well as infrastructural facilities. All these should actually yield dividends of democracy to the people.

\section{References}

Abdulahi, B.F. (2009). Misappropriation and embezzlement of public funds in Nigeria: a critical analysis. Lapai International Journal of Management and Social Sciences, 2 (2), 180198.

Adepoju, T.L. (1998). Fundamentals of school administration, planning and supervision in Nigeria. Atlas Nigeria Company.

Afolabi, E.R.I, Alao, K.A., Aladejana, A.I., Popoola, B.I. \& Omotoso, B.A. (2005).Education, social organization, custom of Nigeria. Baoku Press, Nigeria.

Afolabi, G.K. (2004). Accountability and transparency in governance. Babcock Journal of Management and Social Sciences 3 (1).

Africa-AutoCWW ( no date). Retrieved Dec. 10, 2011 from: autocww.colorado.edu/ toldy2/---/GeographicalRegions/Africa.htm

Aganga, O. (2010). Rising unemployment rate is unacceptable-Goodluck Jonathan. Business Facts and Figures Magazine.

Agu, O.C. (2013). Democracy and the cost of governance in Nigeria. Journal of Culture, Societyand Development. 2, 41-51.

Ajadi, T.O. \& Adedeji, S.O. (2009). Principles of institutional administration.National OpenUniversity of Nigeria, Lagos, Gold Print Ltd., Lagos. ISBN: 978-058-282-7.

Akanbi, M.M. (2004). Corruption, accountability, and good governance” In Saliu H.A. (ed), Nigeria under democratic rule (1999-2003), Ibadan; University Press PLC.

Akpe, A. (2008).Corruption, Poverty, Still High in Nigeria- NEPAD Team, http:www.businessdayonline.com/national/10725.html

Aluko, J.O. (2006). Corruption in the localgovernment system in Nigeria. Book Builders - Editions Africa, Nigeria. ISBN: 978-808 82-3-6.

American Heritage Dictionary, (no date). Retrieved Dec. 4, 2011 from:http://www.answers.com/topic/egypt

Asaju, S., Arome, S.,\& Anyio (2014). The Rising rate of unemployment in Nigeria: the socio-economic and political implications.Global Business and Economics Research Journal, Vol. 3, No. 2.

Bardhan, P. (2005). Scarcity, conflicts and cooperation essays in the political and institutional economic development, Cambridge: the MIT Press. 


\section{I Macrothink}

Journal of Public Administration and Governance

ISSN 2161-7104

2016, Vol. 6, No. 1

Bello, M.L., \& Lamidi, K.O. (2009). An assessment of poverty as a threat to Nigerian fledging democracy. Lapai International Journal of Management and Social Sciences, 2, (2), 380-389.

Claude, A. (1996). Democracy and development in Africa. The Journal of Modern African Studies, 35, (4), 745-778.

Dagaci, A.M. (2009). Democracy and the leadership question: a redefinition in the Nigerian context.Lapai International Journal of Management and Social Sciences, 2, (2). 16-28.

Dickson, C. (2011). Good governance in Nigeria. http://saharareporters.com/article/good-governance-nigeria-tuwo-and- oup-metaphor-prince-c harles-dickson. Retrieved on $19^{\text {th }}$ July, 2012.

Dike, V. E. (2010). Managing the challenges of corruption in Nigeria. Centre for Social Justice and Human Development, Sacramento, California.

Ejuvbekpokpo, S. (2012). Cost of governance on economic development in Nigeria. Global Journalof Management and Business Research,12, (13).

Ibeanu, O. (2008). "Affluence and affliction: The Niger Delta as a critique of political science in Nigeria". An Inaugural Lecture of the University of Nigeria, Nsukka. Delivered on February 20, 2008.

Ijaya, M.,\& Ijaya,G. (2006).Transparency in governance and economic growth in Sub-Saharan Africa: cross country analysis, Babcock Journal of Management and Social Science. 2, (8).

Ikubaje, J.G. (2014).Democracy and anti-corruption in Africa. Department of Political Affairs,African Union Commission. http://www.africansharedvalues.org/en/

Iyoha, F.O., Gberevbie, D.F., Iruonagbe, C.T., \&Egharevba, M.E. (2015). Cost of governance inNigeria: in whose interest? International Journal of Social, Education, Economics and Management Engineering. 9, (1).

Kaufmann D., Kraay, A.,\& Zoido, L. P. (2000).Governance matters: From Measurementto action. IMFFinance and Development. 37, (2).

Khan, M.H. (2007). Governance, economic growth and development since the 1960s", in Jose, A. O., Jomo, K. S. and Rob, V. (Eds.) growth divergences: explaining the differences in economic Performance. Hyderabad, London and Penang: Orient Longman, Zed Books and Third World Network.

Kolade, C. (2012). The possibility of good governance in Nigeria. http:www.businessdayonline.com/NG/index.php/news/111. Retrieved on $17^{\text {th }}$ July, 2012.

Mamora, O. (2012). The possibility of good governance In Nigeria. http:www.businessdayonline.com/NG/index.php/news/111. Retrieved on $17^{\text {th }}$ July, 2012. 


\section{Macrothink}

Journal of Public Administration and Governance ISSN 2161-7104 2016, Vol. 6, No. 1

Nyewusira, V. (2007). Selected socio-political issues in Nigeria:religious institutions as agents of change.Journal of Pedagogy and Educational Development, 12, (1).

Nyewusira, V., \& Nweke. (2014). Nigeria and the attainment of sustainable development in the $21^{\text {st }}$ century. Mediterranean Journal of Social Sciences. 5, (4).

Ogunmade, O. (2013). \$600bn stolen by Nigerian elite since independence. ThisDay LIVE Retrieved on 19/6/13.www.thisdaylive.com/article/\$600bn-stolen-by-nigerian-elite 2014.

Ogwu, J. (2002). The African union and the challenges of development in the $21^{\text {st }}$ Century. No 1 public lecture series of the Faculty of Business and social Sciences, University of Ilorin.

Olomola, A.S. (1996). Socio-cultural and political dimension of development in $21^{\text {st }}$ CenturyNigeria. Africa Rural Social Science Research.

Shobola, A.A., \& Nicholas-Omoregbe, O.S. (2012). A Nigerian personality: panacea for african Leadership. Africa Leadership Review,UK, 4. 137-157.

Soyinka, A. (2014).Untold story of Boko Haram victims. Tell Magazine, September 22, (38), 24-25.

Okeyim, M.O., Ejue, J.B.,\& Ekanem, S.A. (2013). Governance and corruption in Nigeria: a philo-psychologicalanalysis. Net Journal of Social Sciences.1(2), 24-32.UNDP (1998).Human Development Report, Oxford: Oxford University Press.

UN-Habitat (2008). Crime and violence versus employment opportunities in cities and towns. The $2^{\text {nd }}$ African Ministerial Conference on Housing and Urban Development. Abuja, Nigeria.

World Bank (1989). Sub-Saharan Africa: From crisis to sustainable growth: A long-termperspective study.Washington DC: World Bank.

Wikipedia, (no date). Decolonization of Africa. Retrieved Dec.8, 2011 from: http://en.wikipedia.org/wiki/Decolonization_of_Africa

World Bank \& International Monetary Fund (2005). Review of the PRS Approach:BalancingAccountabilities and Scaling UpResults.http://siteresources.worldbank.org/INTPRSI/Resources/PRSP.Review/2005

Yalokwu, P.O. (2006).Fundamentals of management; second edition. African Centre for Management and Education. ISBN 978-079-254-6. 